\title{
Is US Bank Lending Sensitive to Exchange Rates? A Panel Data Investigation
}

\author{
Michael R. Jonas \\ Department of Economics, University of San Francisco, San Francisco, CA, USA \\ Email: mrjonas@usfca.edu
}

Received 14 May 2014; revised 7 June 2014; accepted 4 July 2014

Copyright (C) 2014 by author and Scientific Research Publishing Inc.

This work is licensed under the Creative Commons Attribution International License (CC BY).

http://creativecommons.org/licenses/by/4.0/

c) (i) Open Access

\section{Abstract}

The goal of this paper is to examine the sensitivity of US bank lending to movements in the exchange rate. Using a panel of quarterly bank-level balance sheet observations, I show that there exists significant and meaningful exchange rate sensitivity of cross-border lending activity and total domestic loans. This relationship operates through traditional net export channels, as well as mechanisms specific to banks engaged in international lending. Further, I show that exchange rate innovations represent a source of long run lending volatility equivalent to monetary policy shocks for small banks. Lastly, exchange rate movements are shown to be associated with a four-fold increase in growth of non-performing loans for small banks, providing direct evidence of transfer risk for cross-border banks.

\section{Keywords}

Cross-Border Banking, Exchange Rates, Monetary Policy, Bank Lending Channel

\section{Introduction}

The expansion of global and cross-border activity in the US banking industry has undoubtedly altered many aspects of the "special role" that banks play in the economy. One issue of particular interest is an increased sensitivity of domestic bank lending to currency valuation. The conjecture of this paper is twofold: first, banks that engage in cross-border lending will have a greater sensitivity of total lending to exchange rates, meaning that currency effects "spill-over" from foreign lending to domestic lending; second, that all banks, be they crossborder or purely domestic, are sensitive to currency valuation.

Bank lending sensitivity to international capital flows and exchange rate shocks is far from a new concept, with obvious examples drawn from the current situation in Europe and dating back to the Asian financial crisis of $1997^{1}$. In fact, the idea that financial intermediation in small open economies is at least as sensitive to currency

${ }^{1}$ See, for example Radelet, et al. [1] and Corsetti [2]. 
valuation as to domestic interest rates is a foundation of international finance literature. The question that remains unaddressed is whether or not this sensitivity occurs in the banking industry of large, relatively closed economies such as the US. The implications of the existence of a significant lending sensitivity to exchange rates in US banks are twofold: first, this would represent a source of volatility outside the control of a Federal Reserve unwilling or unable to engage in foreign exchange interventions, counteracting or exacerbating intended policy effects. Second, an additional source of differentiation in behavior and response to policy across banks may be embodied in the degree of cross-border activity and exchange rate sensitivity.

This paper addresses this question by analyzing the impact of exchange rate movements on bank behavior over a panel of all US banks across 68 quarters of Call Report data. Evidence is found for significant sensitivity not only of cross-border lending, but of total domestic lending, as well. Indeed, total lending for small banks is found to be more responsive to exchange rate shocks than to interest rate shocks.

The remainder of this paper is organized as follows: Section 2 outlines the likely sources of US lending sensitivity to currency fluctuations. Section 3 presents this examination in the context of related literature. Section 4 introduces the bank level and macro data used in the analysis. Section 5 presents the econometric specification and empirical evidence on the impact of currency valuation on US bank lending. Section 6 concludes.

\section{Channels of Lending Sensitivity to Currency Fluctuations}

There are three primary channels by which a change in the value of domestic currency may impact a bank's lending activity. First, and most obviously, firms that borrow from banks may have import/export business activity that depends on exchange rate movements — as their cash flow changes, their demand for loans will follow. This channel will potentially exist for all banks, and will manifest itself in a higher sensitivity of commercial and industrial loans to exchange rate movements.

Second, banks that engage in cross border lending such that the loans are denominated in foreign currency will face risk associated with currency mismatch. An appreciation of domestic currency will translate to a reduction in the dollar value of these assets. While this effect in emerging markets and small, open economies is well known (see [3], for example), its existence in US banking has not yet been empirically established. Reference [4] finds that the major factor in driving down cross-border lending of European banks in the 2007-2008 crisis was the downturn in global trade, rather than country-specific or currency-specific shocks. This suggests that currency mis-match was not a major factor for European banks during the crisis.

Lastly, cross-border lending denominated in dollars will still face currency sensitivity due to transfer risk. Reference [5] defines transfer risk to US banks as the risk associated with loan default by foreign borrowers due to an inability to obtain sufficient dollars to repay loans denominated in dollars. This risk will be present in foreign lending, even when denominated in dollars, which is the case for the majority of US cross-border lending.

The current composition of the US banking industry indicates that the combined effects of these channels are likely to be large. As shown in [4], the share of total US banking assets held by globally active banks is well over $60 \%$. These banks are predominantly very large, and thus relatively insensitive to balance sheet and policy shocks (see [6] and [7], among others) due to the ability to access external sources of funds. In addition, [8] show that globally active banks have the ability to tap into internal capital markets-shifting assets across borders-further insulating their domestic lending to shocks. However, their lending may still be sensitive to exchange rate movements.

Figure 1 shows the currency composition of foreign lending and deposit taking activities of US banks. Clearly, the vast majority of cross-border loans which originate in the US, and deposits originating abroad, are denominated in dollars, and thus not subject to currency mismatch risk on the part of the lending institution. The foreign borrower, however, will be subject to transfer risk, and therefore dollarized loans are not immune from currency valuation shocks.

Figure 2 shows the overall trend of total foreign currency denominated assets, with a sharp run-up prior to the financial crisis and recession of 2008. While a small fraction of total lending, the nearly six-fold increase between 2003 and 2007 represents a major shift in the level of US bank currency risk exposure.

Figure 3 shows the general trend of the valuation of the US dollar, with a peak prior to the 2001 recession and general decline since. The over 30\% decline in the value of the dollar between 2001 and 2009 undoubtedly influenced US productivity growth, investment, and trade (see [9]), but the influence on bank activity is a question unaddressed by the literature thus far. 


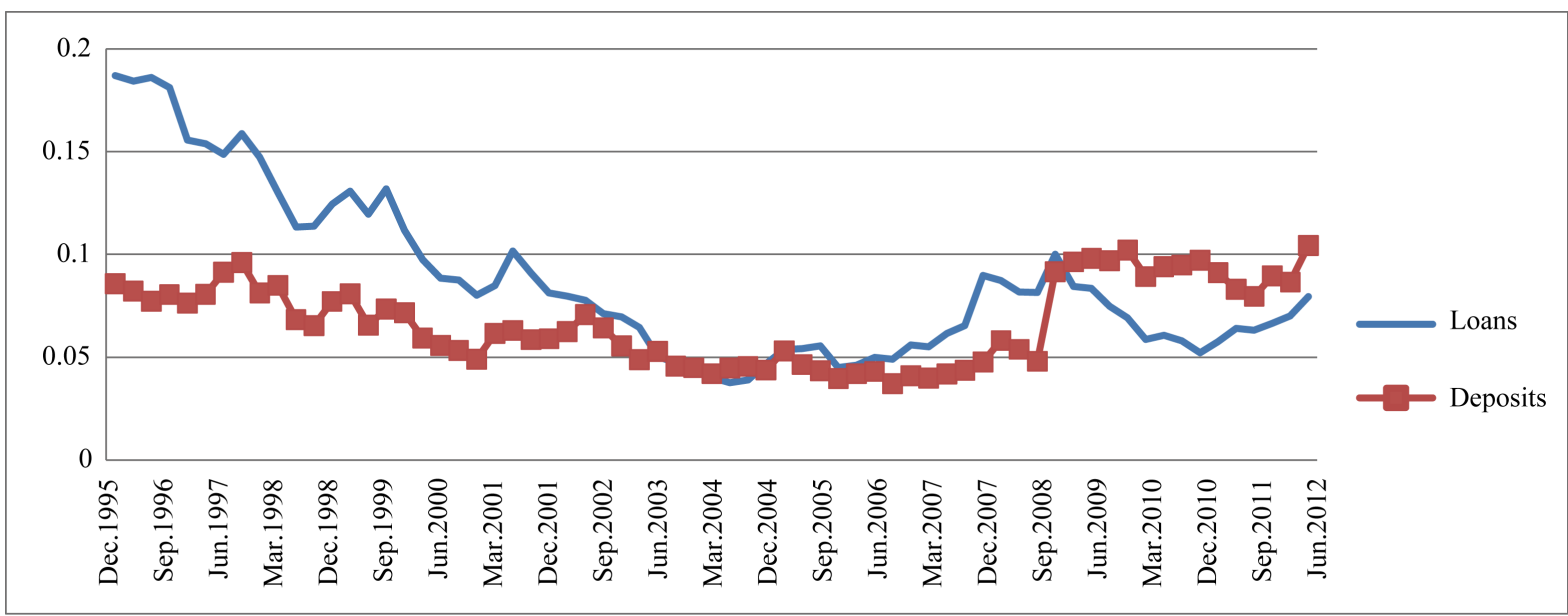

Figure 1. US bank foreign currency loans and deposits as percent of total external assets and liabilities. Source: Bank of international settlements. External positions of banks in foreign currencies vis-à-vis all sectors.

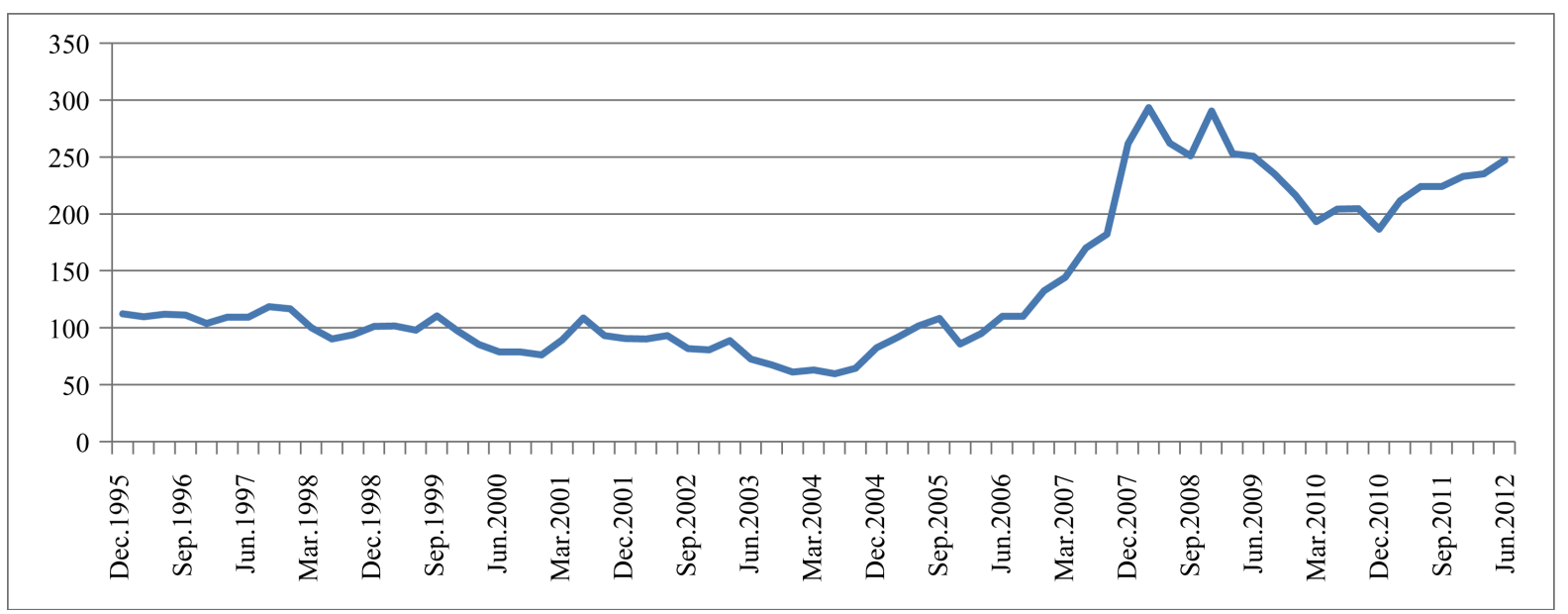

Figure 2. Total foreign currency assets of US banks (\$BN). Source: Bank of international settlements. External positions of banks in foreign currencies vis-à-vis all sectors.

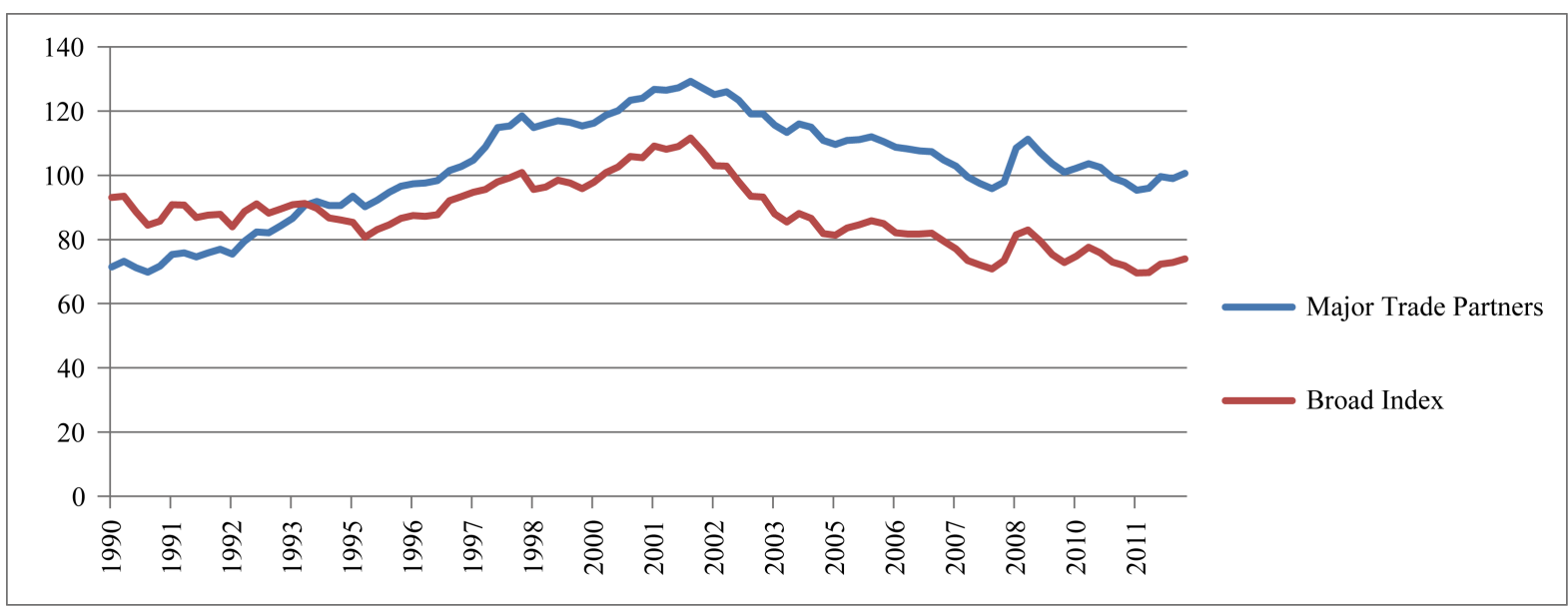

Figure 3. US dollar trade-weighted exchange rate indices. Source: Federal reserve economic database. Broad index is nominal TWEXBMTH series, with $1997=100$, not seasonally adjusted. Major trade partner index is nominal TWEXOMTH series, with $1997=100$, not seasonally adjusted. 


\section{Related Literature}

A large number of recent empirical and theoretical studies focused on small open economies have shown definitively that increased globalization in trade and capital flows results in a significant reduction in the role of traditional interest rate channels of the monetary transmission mechanism, while increasing the role of exchange rates and net exports (see, for example [10]).

Reference [11] develops a dynamic macroeconomic model to consider the theoretical effects of increased globalization of financial, output, and factor markets on the ability of policy makers to control domestic inflation. While the sensitivities of interest rates, output, and inflation to policy are reduced through increased global linkages, the basic mechanisms of control are not fundamentally altered.

Reference [12] examines the role of exchange rates in determining optimal monetary policy in Germany by estimating a structural VAR model. They show that the impact of policy on inflation is accelerated by the exchange rate channel. While not directly examining lending activity vis-à-vis exchange rates, this study suggests an interaction between the banking sector and currency valuation at the macro level.

The traditional view of the role played by the exchange rate in bank lending is that it operates through net exports reacting to policy induced changes in exchange rates. Increasingly, however, the way in which economies interact with one another across currencies is through capital flows and linkages of financial instruments, rather than the flow of goods and services. As pointed out in [13], these linkages have a variety of effects on bank lending in large economies, as well as small, open economies. The effects include a weakening of the link between domestic short- and long-term interest rates, as long-term rates are increasingly set in international markets. There is also an increase in domestic sensitivity to global shocks, and corresponding weakening of policy makers' targeting regimes. Like [11] [13] finds that monetary policy makers under floating exchange rate regimes retain the ability to control short term interest rates and thus affect domestic output and inflation.

For banks in a small open economy, the problem of currency mismatch involves matching dollar denominated assets with a corresponding amount of dollar denominated liabilities. The cost of achieving this goal will depend on the exchange rate regime of the home country. Reference [14] shows that floating exchange rate regimes in developing and transition economies facilitate dollarization of deposits to a greater extent than loans, and actually correlate with a larger degree of mismatch compared to fixed regime economies. The logic is that the increased volatility associated with a flexible regime increases the cost of proper hedging, and thus encourages a greater mismatch. This result is useful for the question of currency risk of cross-border loans originating in the US in that it suggests that borrowers of dollars in flexible regime countries will face greater uncertainty and hedging cost, and thus greater difficulty in matching the value of domestic currency income to dollarized values of their liabilities. This all translates into a greater degree of transfer risk borne by US banks making cross-border dollarized loans.

\section{Data Description}

The analysis uses a panel of quarterly "Call Report” data of balance sheet outcomes for all US banks and bank holding companies which spans from 1990Q1 to 2007Q12. The data series begins in 1990 due to the lack of available consistent time series for key variables prior to that date. The truncation at 2007 is to avoid the influence of the financial crisis and recession which began quarter 1 of 2007. While regrettable, the removal of observations during the financial crisis is deemed necessary to due to the unprecedented alteration in bank behavior that will confound the ability to distinguish the influence of specific factors. In all, the panel consists of 181,637 bank-quarters of data.

The key balance sheet variables for this analysis will be measures of foreign currency exposure and participation in cross-border lending. The following indicators are gathered for each bank at each quarter:

- Commercial and Industrial Loans to Non-US Addresses (RCFD1764 or RCON1764)

- Loans to Foreign Governments and Official Institutions (RCFD2081)

- Loans to Banks in Foreign countries (RCFD1510 or RCFNB535)

- Balances Due from foreign branches of other US Banks (RCON0073)

- Balances Due from Banks in foreign countries and foreign central banks (RCFD0070)

${ }^{2}$ FFIEC 031 “Consolidated Reports of Condition and Income for a Bank with Domestic and Foreign Offices” and FFIEC 041 "Consolidated Reports of Condition and Income for a Bank with Domestic Offices Only”. 
From this, an overall indicator is constructed such that we define

$$
\text { Cross-Border Loans = RCFD1764 + RCFD2081+ RCFD0070 + RCON0073 }
$$

A “cross-border” bank will be defined as any bank with Cross-Border Loans $>0$.

Table 1 shows the distribution of cross-border bank activity in 2006Q1 by assets size class, where bank size is determined by percentile rank of total nominal assets. Several key characteristics of cross-border banks become apparent. First, as expected, banks in the larger size categories are much more likely to engage in cross-border lending, with fewer than $1 \%$ of banks in the bottom 75 th percentile falling into that category, but $35 \%$ of the largest banks. However, smaller banks that do engage in cross-border lending, do so at larger relative magnitudes, with the average small cross-border bank having $11 \%$ of total loans exposed to direct foreign currency risk, with only $2.8 \%$ for the largest banks.

Another striking outcome of Table 1 is the percent of total assets controlled by cross-border banks. For small to mid-size banks, the asset holdings of cross-border banks are roughly on the same order of magnitude as their percentage of the population, but for banks in the top 5\% of the assets distribution, cross-border banks hold a much larger than proportional percentage of total assets.

Figure 4 indicates the huge and persistent discrepancy that exists between large and small banks in terms of the prevalence of cross-border lending activity. While the larger banks are much more likely to engage in cross-border lending, they are also more equipped to absorb exchange rate shocks.

Figure 5 shows that among those banks in the largest size category, cross-border loans make up a non-trivial portion of total lending, and thus the potential for currency mismatch risk is present.

For empirical analysis, macro-level time series variables used will come from one of three categories: exchange rates, a monetary policy indicator, and domestic cyclical control variables. Domestic cyclical indicators will be unemployment rate, consumer price index, and housing price index. Following convention ([15], etc.), the primary policy indicator will be the first difference in the Federal Funds rate.

Domestic currency valuation will be measured with the first difference in the broad and major currency indices, as well as values of the UK Pound, Canadian dollar, Euro, and Chinese Renminbi as individual currencies relative to the US dollar. Each valuation is a measure of the foreign exchange value of the US dollar against the foreign currencies, thus, an increase in the value of the index represents an appreciation of the US dollar.

Table 1. Stock of total cross-border loans by bank size (2006Q1).

\begin{tabular}{|c|c|c|c|c|c|}
\hline & $\begin{array}{l}\text { Small (Below 75th } \\
\text { percentile) }\end{array}$ & $\begin{array}{l}\text { Small-Mid (75th - } \\
\text { 90th percentile) }\end{array}$ & $\begin{array}{l}\text { Mid-Size (90th - } \\
\text { 95th percentile) }\end{array}$ & $\begin{array}{l}\text { Large-Mid (95th - } \\
\text { 99th percentile) }\end{array}$ & $\begin{array}{c}\text { Large } \\
\text { (99th percentile) }\end{array}$ \\
\hline Total Number of Obs. & 6192 & 1239 & 413 & 329 & 84 \\
\hline Number cross-border banks & 54 & 103 & 59 & 118 & 29 \\
\hline Ratio & 0.009 & 0.08 & 0.14 & 0.36 & 0.34 \\
\hline $\begin{array}{l}\text { Mean Total Assets of } \\
\text { cross-border banks }\end{array}$ & $\$ 140$ mil & $\$ 485$ mil & $\$ 1.1$ bil & $\$ 6.4$ bil & $\$ 45.2$ bil \\
\hline $\begin{array}{l}\text { Mean Cross-Border Loans } \\
\text { of cross-border banks }\end{array}$ & $\$ 16.6$ mil & $\$ 36 \mathrm{mil}$ & $\$ 66.8 \mathrm{mil}$ & $\$ 205$ mil & $\$ 1.28$ bil \\
\hline Cross-border Loan Ratio & 0.11 & 0.074 & 0.06 & 0.03 & 0.028 \\
\hline $\begin{array}{c}\text { Mean Total Assets of } \\
\text { non-cross-border banks }\end{array}$ & \$101 mil & $\$ 450 \mathrm{mil}$ & $\$ 1.1$ bil & $\$ 5.07$ bil & $\$ 134$ bil \\
\hline $\begin{array}{l}\text { Mean Foreign C\&I Loans } \\
\text { of cross-border banks }\end{array}$ & $\$ 12.9 \mathrm{mil}$ & $\$ 21 \mathrm{mil}$ & $\$ 44.7 \mathrm{mil}$ & $\$ 123$ mil & $\$ 788 \mathrm{mil}$ \\
\hline $\begin{array}{l}\text { Assets held by cross-border } \\
\text { banks/Total Assets }\end{array}$ & 0.008 & 0.085 & 0.126 & 0.552 & 0.887 \\
\hline
\end{tabular}

Source: Call Report data. Cross-Border bank defined as any US bank with "Cross-border lending” = RCFD1764 + RCFD2081 + RCFD0070 + RCON0073 > 0. Total Assets defined as RCFD2170. Size categories based on percentiles of total nominal assets by quarter. Cross-border Loan Ratio is calculated as Cross-border Loans/Total Assets. 


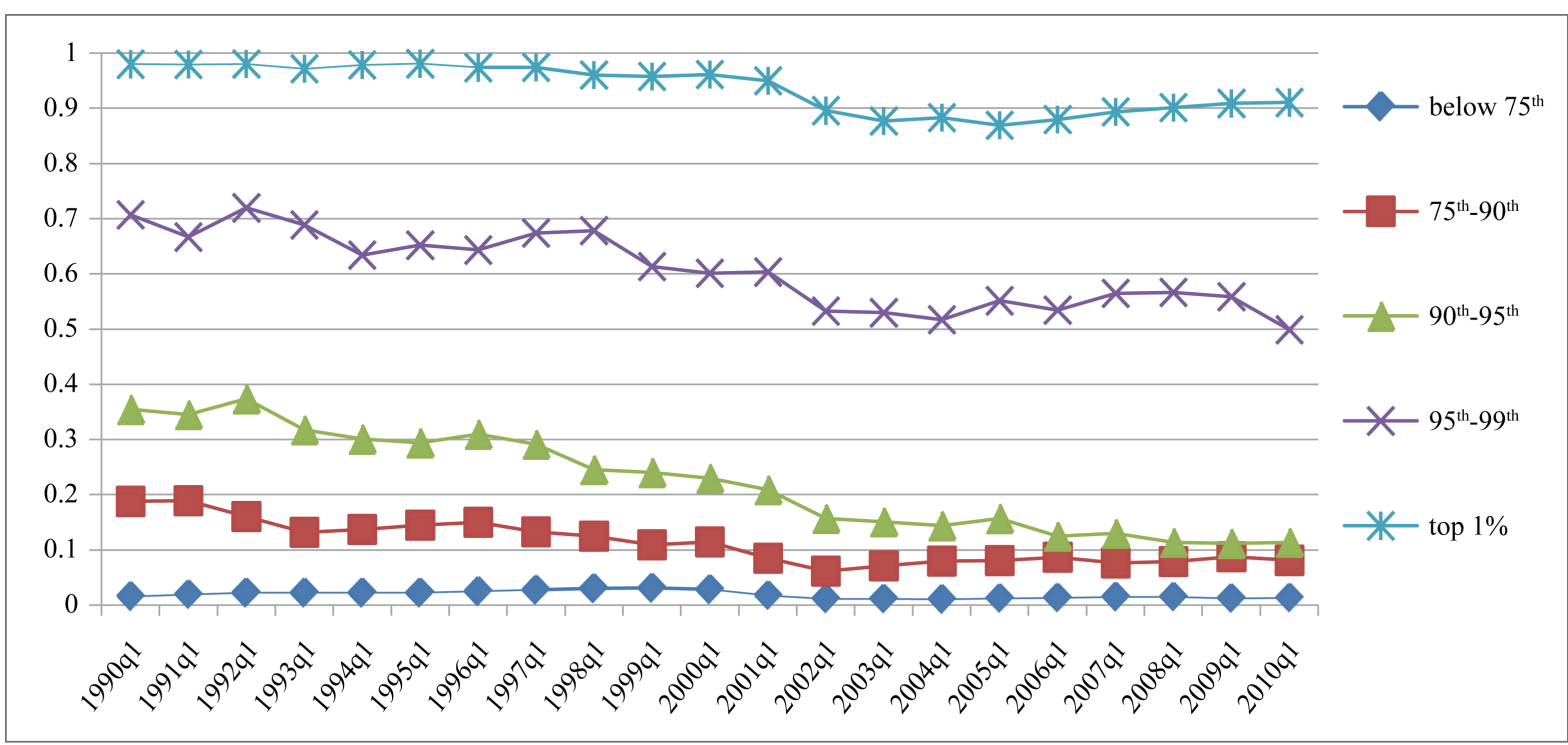

Figure 4. Percent of total assets controlled by cross-border banks by size category. Source: Call report data. Cross-Border bank defined as any US bank with "Cross-border lending" = RCFD1764 + RCFD2081 + RCFD0070 + RCON0073 > 0 . Total Assets defined as RCFD2170. Size categories based on percentiles of total nominal assets by quarter.

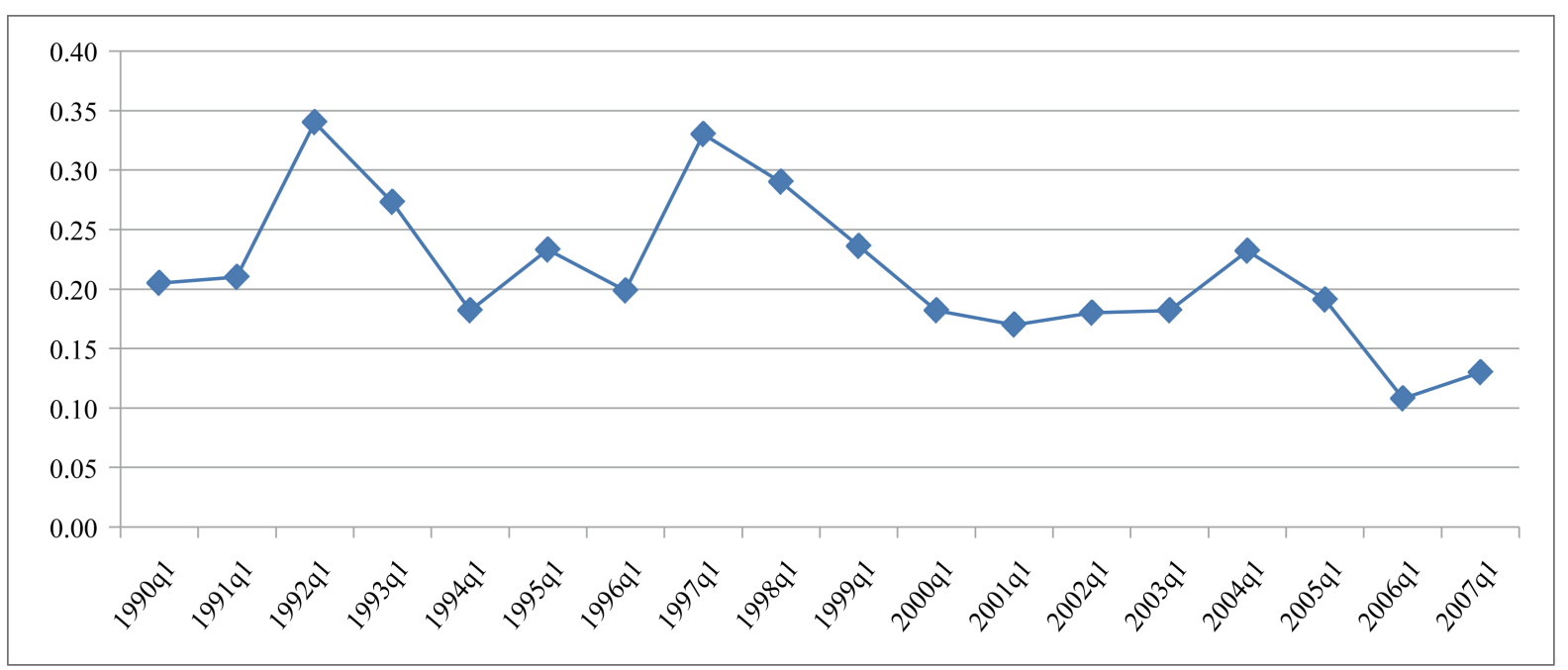

Figure 5. Ratio of cross-border loans to total net loans for large banks. Source: Lending data obtained from Call Reports. Cross border loans are defined as the sum of Commercial and Industrial Loans to Non-US Addresses (RCFD1764), Loans to Foreign Governments and Official Institutions (RCFD2081), Loans to Banks in Foreign countries (RCFD1510 or RCFNB535), Balances Due from foreign branches of other US Banks (RCON0073) and Balances Due from Banks in foreign countries and foreign central banks (RCFD0070). A "Large Bank" is any bank in the first percentile of total assets in a given quarter.

As a first glance at the potential for exchange rate sensitivity of cross-border lending across bank size categories, Table 2 reports simple pair-wise correlation coefficients in first differences. While difficult to interpret in terms of magnitude, the pattern that emerges shows that as the dollar appreciates (the index increases), the value of cross-border loans on bank balance sheets declines. This result is broadly consistent with the currency mismatch and transfer risk hypotheses.

\section{Empirical Strategy and Results}

The sensitivity of bank lending to exchange rates is tested using three distinct regression strategies. First, a series 
Table 2. Correlations between first differences of cross-border lending and exchange rate indices—full sample.

\begin{tabular}{cccccc}
\hline & $\begin{array}{c}\text { Small (Below 75th } \\
\text { percentile) }\end{array}$ & $\begin{array}{c}\text { Small-Mid (75th - } \\
\text { 90th percentile) }\end{array}$ & $\begin{array}{c}\text { Mid-Size (90th - } \\
\text { 95th percentile) }\end{array}$ & $\begin{array}{c}\text { Large-Mid (95th - } \\
\text { 99th percentile) }\end{array}$ & $\begin{array}{c}\text { Large } \\
\text { (99th percentile) }\end{array}$ \\
\hline Total Number of Obs. & 519,582 & 103,920 & 34,641 & 27,708 & 8710 \\
$\begin{array}{c}\text { Total cross-border lending } \\
\text { vs. Broad Index }\end{array}$ & -0.0033 & -0.0002 & -0.0030 & -0.0004 & -0.0094 \\
$\begin{array}{c}\text { Total cross-border lending } \\
\text { vs. Major Index }\end{array}$ & -0.0038 & -0.0002 & -0.0047 & 0.0034 & -0.0047 \\
\hline
\end{tabular}

of dynamic first-difference and fixed effects panel models will directly estimate the short- and long-term sensitivities of total net lending to policy and exchange rate shocks. Second, first difference models are used to isolate the transfer and currency risk of cross-border loans. Lastly, non-accruing loans are shown to be more sensitive to exchange rate movements for cross-border banks, results which are consistent with the argument for transfer and currency mismatch risk.

\subsection{Regression Model 1: Total Net Loan Sensitivity to Exchange Rates-All Banks}

In order to establish the direct link between exchange rates and lending, an equation is estimated with the level of total net loans as the dependent variable, and an exchange rate index as the key explanatory variable. Additional control variables are included in order to account for overall economic conditions as well as bank-level balance sheet effects. To proxy for overall economic conditions, and thus loan demand, contemporaneous and lagged values of the civilian unemployment rate, broad consumer price index, and the housing price index are included. Following [16] and [17], bank equity-to-asset ratio and total deposits are used to control for bank level access to liquidity and balance sheet shocks. The Federal Funds rate is used to account for policy shocks, as well as a measure of overall liquidity supply to banks. Finally, three quarterly dummies are included to account for cyclical shocks and seasonal lending patterns. Contemporaneous values of balance sheet indicators are omitted to avoid an endogenous outcome with lending. All variables are either first differences or in fixed effects quasi-differences, to account for potential non-stationarity, as well as unobserved heterogeneity correlated with the explanatory factors. Random effects estimates, and thus those from pooled OLS without differencing, are shown to contain significant bias through the Hausman coefficient test performed on all asset size categories. Additionally, to avoid bias due to mergers, entry and exit, only banks that appear in at least 60 quarters within the sample are included.

An instrumental variables approach is used to control for endgoeneity of the lagged dependent variable in a panel first-difference regression (see [18]). The second lag of the differenced dependent variable is used as the instrument for the first lag. This will provide consistent estimates under the condition that the error is not serially correlated. This is shown to be the case for each size category using the Arellano-Bond [19] test for autocorrelation in panel first-differenced errors. This is sufficient to show exogeneity of the instruments in the case of a dynamic panel regression. In addition, bootstrap heteroskedasticity robust standard errors are used.

$$
\begin{aligned}
\text { LlogNetLoans }_{i t}= & \sum_{j} \beta_{i} \Delta E R_{t-j}+\sum_{j} \delta_{j} \text { CBLNS }_{i, t-j} * \Delta E R_{t-j} \\
& +\sum_{j}^{4} \gamma \Delta F F R_{t-j}+\rho \Delta \text { NetLoans }_{i, t-1}+\text { CONTROLS }
\end{aligned}
$$

where CBLNS is the total amount of cross-border loans on the balance sheet of bank $i$, at time $t-j$. Four lags of each variable are included to allow adequate time for adjustment (as in [7] and [8]). This lag structure is also in accordance with a minimization of AIC and SIC in the majority of the size-specific regressions.

Table 3 shows that, controlling for changes in the Federal Funds rate, there are significant exchange rate effects on total net loans across all bank size categories other than the top 5\%. Further, the interaction terms indicate that banks with larger values of foreign loans have a greater exchange rate sensitivity of net loans. This is evidence of the second two hypothesized channels: transfer and currency mismatch risk.

The greatest exchange rate sensitivity occurs in the small bank sector. All four quarterly lag coefficients are negative and significant. This is consistent with transfer and currency risk balance sheet effects developing over time through cross-border lending. An increase in exchange rate index is associated with a weakening of the 
Table 3. Exchange rate sensitivity of total net lending (Broad index). Panel dynamic first difference specification. Estimation sample 1990Q1-2007Q1. Autoregressive term is instrumented with second lag in differenced Log Total Net Lending. Additional Controls include four lags of unemployment, CPI, housing price index, single lag of bank level equity-asset ratio, single lag of total deposits, three quarterly dummy variables.

\begin{tabular}{|c|c|c|c|c|c|}
\hline & \multicolumn{5}{|c|}{ Bank Size } \\
\hline & Smallest 75th & 75th - 90th & 90th - 95th & 95th - 99th & Top 1\% \\
\hline \multicolumn{6}{|l|}{$\Delta$ EX.RATE } \\
\hline Lag 1 & $\begin{array}{c}-0.00042^{* * *} \\
(0.001)\end{array}$ & $\begin{array}{c}-0.00010 \\
(0.640)\end{array}$ & $\begin{array}{c}-0.00037 \\
(0.349)\end{array}$ & $\begin{array}{c}-0.00014 \\
(0.844)\end{array}$ & $\begin{array}{l}0.00136 \\
(0.449)\end{array}$ \\
\hline Lag 2 & $\begin{array}{c}-0.00052^{* * *} \\
(\mathbf{0 . 0 0 0 )}\end{array}$ & $\begin{array}{c}-0.00123^{* * *} \\
(0.000)\end{array}$ & $\begin{array}{c}-0.00157^{* * *} \\
(0.000)\end{array}$ & $\begin{array}{c}-0.00110 \\
(0.110)\end{array}$ & $\begin{array}{l}0.00146 \\
(0.725)\end{array}$ \\
\hline Lag 3 & $\begin{array}{c}-0.00045^{* * *} \\
(\mathbf{0 . 0 0 0 )}\end{array}$ & $\begin{array}{l}0.00021 \\
(0.302)\end{array}$ & $\begin{array}{l}0.00023 \\
(0.522)\end{array}$ & $\begin{array}{c}-0.00043 \\
(0.517)\end{array}$ & $\begin{array}{c}0.00070 \\
(0.757)\end{array}$ \\
\hline Lag 4 & $\begin{array}{c}-0.00026 * * * \\
(0.017)\end{array}$ & $\begin{array}{c}-0.00033 \\
(0.104)\end{array}$ & $\begin{array}{l}0.00047 \\
(0.200)\end{array}$ & $\begin{array}{c}-0.00005 \\
(0.939)\end{array}$ & $\begin{array}{c}0.00338 \\
(0.584)\end{array}$ \\
\hline $\begin{array}{c}\Sigma \Delta \mathrm{EXX}_{\mathrm{RATE}} \\
\text { (p-value F-stat) }\end{array}$ & $\begin{array}{c}-0.00164^{* * *} \\
(0.000)\end{array}$ & $\begin{array}{c}-0.00145^{* * *} \\
(0.000)\end{array}$ & $\begin{array}{c}-0.00123^{* *} \\
(0.039)\end{array}$ & $\begin{array}{c}-0.00172 \\
(0.107)\end{array}$ & $\begin{array}{c}0.00694 \\
(0.533)\end{array}$ \\
\hline $\begin{array}{l}\text { One Std. Dev. Rise in } \\
\text { ER associated with } \\
\text { fall in Lending of }\end{array}$ & $0.36 \%$ & $0.31 \%$ & $0.27 \%$ & - & - \\
\hline $\begin{array}{c}\Sigma \Delta \text { EX.RATE }{ }_{\mathrm{t}-\mathrm{i}}^{*} \\
\text { (cross-bdr loans) } \\
\text { (p-value F-stat) }\end{array}$ & $\begin{array}{c}-6.86 e^{-08} 8^{* * *} \\
(0.001)\end{array}$ & $\begin{array}{l}-3.61 \mathrm{e}-09 \\
(0.174)\end{array}$ & $\begin{array}{l}-1.54 \mathrm{e}^{-09} \\
(0.570)\end{array}$ & $\begin{array}{c}-5.69 e^{-10 * *} \\
(0.011)\end{array}$ & $\begin{array}{l}-7.71 \mathrm{e}^{-11} \\
(0.650)\end{array}$ \\
\hline $\begin{array}{c}\Sigma \Delta \mathrm{FFR}_{\mathrm{t}-\mathrm{i}} \\
\text { (p-value F-stat) }\end{array}$ & $\begin{array}{c}-0.00267^{* *} \\
(0.033)\end{array}$ & $\begin{array}{c}0.00155 \\
(0.503)\end{array}$ & $\begin{array}{c}0.00173 \\
(0.677)\end{array}$ & $\begin{array}{c}-0.00715 \\
(0.342)\end{array}$ & $\begin{array}{c}0.03618 \\
(0.260)\end{array}$ \\
\hline Number of obs. & 408,261 & 76,354 & 23,432 & 17,507 & 4312 \\
\hline Number of Groups & 9677 & 3155 & 1231 & 750 & 148 \\
\hline R-sq: within/betw/overall & $0.274 / 0.961 / 0.977$ & $0.267 / 0.856 / 0.852$ & 0.010/0.792/0.553 & $0.008 / 0.865 / 0.381$ & $0.107 / 0.905 / 0.696$ \\
\hline
\end{tabular}

p-values in parentheses. ${ }^{*}=$ significant at $10 \%,{ }^{* *}=$ significant at $5 \%,{ }^{* * *}=$ significant at $1 \%$.

bank balance sheet as foreign borrowers find it more costly to convert domestic currency into dollars, and a corresponding reduction in lending. This is also consistent with domestic loan demand falling due to net exporting firms seeing a decrease in demand for their products as their relative price increases along with the value of the dollar.

The magnitudes of the coefficients indicate a non-trivial response. Given that the dependent variable is the differenced log of net loans, the magnitudes of each coefficient must be interpreted as a partial elasticity with respect to the first difference in the exchange rate index. Over the first four quarters following a one standard deviation increase in the broad exchange rate index, small banks will experience a cumulative decrease in the growth of total lending of over three-tenths of a percent. Following the largest increase in the differenced index experienced in the sample period, the four quarter response in small bank lending would be a nearly one percent decrease in growth. A valid point of comparison is the long-run impact over the same four period horizon of a one standard deviation increase in the differenced Federal Funds rate. The impact on small banks is estimated to be a negative 1 tenth of a percent effect on lending growth. This indicates that, taking into account the likely size of shocks, small banks are roughly three times more responsive to exchange rate shocks as to interest rate shocks.

The negative and significant long run propensity of the interaction between exchange rate and cross-border lending further confirms the role of transfer risk and currency mismatch. Small banks with positive and increasing levels of cross border lending experience a greater, more negative, lending impact of a dollar depreciation. A representative small bank with a first difference of cross-border loans one standard deviation above the sample mean will experience a four quarter cumulative reduction in loan growth of approximately one-half percent 
following a one standard deviation rise in the differenced dollar index.

Comparing the small bank results to the other size categories, we see that all other significant exchange rate coefficients are negative, and of roughly equal magnitudes. Table 3 reports one standard deviation exchange rate index effects for the 75th - 90th, and 90 - 95th percentiles, where the impacts were found to be significant. Again, we see an inverse relationship between exchange rate index and lending. This can be explained in two ways. Larger banks will tend to have larger firms as borrowers, and these firms are much more likely to have access to foreign markets and thus their loan demand will depend positively on exports. As shown in [20] and [21], among others, small banks specialize in relationship lending, primarily with small firms in geographic proximity. Second, as seen in Table 1, larger bank sizes have a larger proportion of banks involved in crossborder lending, thus the balance sheet effects of currency and transfer risk will be more widely felt. Again, this interpretation is validated in the interaction terms. We see that three of the four significant interaction terms are negative, indicating foreign lending exacerbates exchange rate sensitivity of domestic lending.

The largest banks, in the top $1 \%$ asset class, do not exhibit any sensitivity of domestic lending to exchange rates. While this is the asset class shown to be most heavily engaged in cross-border lending, these banks also have the greatest ability to absorb shocks without affecting lending.

Also consistent with monetary policy literature using panel data disaggregated by asset size ([7] etc.), we see only the small banks exhibit significant negative long run responses to the Federal Funds rate.

Table 4 shows the relationship between total net lending and a more narrowly defined exchange rate index which measures the value of the US dollar relative to a basket of only the widely circulating major currencies (currencies from Euro area, Japan, Canada, Switzerland, United Kingdom, Australia, and Sweden). The specification is otherwise identical to that of Table 3.

Again, the results for the smallest asset size category show a very strong sensitivity of net lending to exchange rate movements, with the direction of the response consistent with the hypothesized channels. As previously, assuming a one standard deviation shock to the exchange rate index, we find an estimated reduction in loan

Table 4. Exchange rate sensitivity of total net lending (Major currency index). Panel dynamic first difference specification. Estimation sample 1990Q1-2007Q1. Autoregressive term is instrumented with second lag in differenced Total Net Lending. Additional controls include four lags of unemployment, CPI, housing price index, single lag of bank level equity-asset ratio, single lag of total deposits, three quarterly dummy variables.

\begin{tabular}{|c|c|c|c|c|c|}
\hline & \multicolumn{5}{|c|}{ Bank Size } \\
\hline & Smallest 75th & 75th - 90th & 90th - 95th & 95th - 99th & Top 1\% \\
\hline \multicolumn{6}{|l|}{$\triangle \mathrm{EX} . \mathrm{RATE}$} \\
\hline Lag 1 & $\begin{array}{c}-9.70 \mathrm{e}-06 \\
(0.928)\end{array}$ & $\begin{array}{c}0.00067^{* * *} \\
(0.001)\end{array}$ & $\begin{array}{c}0.00060^{*} \\
(0.081)\end{array}$ & $\begin{array}{c}\text { 0.00111 }^{*} \\
(0.077)\end{array}$ & $\begin{array}{l}0.00186 \\
(0.368)\end{array}$ \\
\hline Lag 2 & $\begin{array}{c}-0.00042^{* * * *} \\
(0.000)\end{array}$ & $\begin{array}{c}-0.00059^{* * *} \\
(0.001)\end{array}$ & $\begin{array}{c}-0.00052 \\
(0.119)\end{array}$ & $\begin{array}{c}0.000042 \\
(0.943)\end{array}$ & $\begin{array}{c}0.00400 \\
(0.499)\end{array}$ \\
\hline Lag 3 & $\begin{array}{c}-0.00038^{* * *} \\
(0.000)\end{array}$ & $\begin{array}{c}0.00033^{* * *} \\
(0.005)\end{array}$ & $\begin{array}{l}0.00018 \\
(0.553)\end{array}$ & $\begin{array}{c}-0.00099^{*} \\
(0.066)\end{array}$ & $\begin{array}{c}0.00075 \\
(0.783)\end{array}$ \\
\hline Lag 4 & $\begin{array}{c}-0.00058^{* * *} \\
(0.000)\end{array}$ & $\begin{array}{c}-0.00044^{* *} \\
(0.013)\end{array}$ & $\begin{array}{c}-0.00001 \\
(0.966)\end{array}$ & $\begin{array}{c}-0.00078 \\
(0.175)\end{array}$ & $\begin{array}{c}0.00248 \\
(0.612)\end{array}$ \\
\hline $\begin{array}{c}\Sigma \Delta \text { EX.RATE }_{\mathrm{t}} \\
\text { (p-value F-stat) }\end{array}$ & $\begin{array}{c}-0.00139 * * * \\
(0.000)\end{array}$ & $\begin{array}{c}-0.00004 \\
(0.901)\end{array}$ & $\begin{array}{c}0.00025 \\
(0.645)\end{array}$ & $\begin{array}{c}-0.00062 \\
(0.528)\end{array}$ & $\begin{array}{c}0.00900 \\
(0.434)\end{array}$ \\
\hline $\begin{array}{c}\Sigma \Delta \mathrm{EX} \mathrm{RATE}_{\mathrm{t}-\mathrm{i}}{ }^{*} \\
\text { (cross-bdr loans) } \\
\text { (p-value F-stat) }\end{array}$ & $\begin{array}{c}-8.04 e^{-088^{* * *}} \\
(0.001)\end{array}$ & $\begin{array}{c}-4.10 \mathrm{e}-09 \\
(0.214)\end{array}$ & $\begin{array}{c}-5.58 \mathrm{e}-10 \\
(0.861)\end{array}$ & $\begin{array}{c}-8.38 e^{-10} 0^{* * *} \\
(0.005)\end{array}$ & $\begin{array}{c}-6.57 \mathrm{e}^{-11} \\
(0.663)\end{array}$ \\
\hline $\begin{array}{c}\Sigma \Delta \mathrm{FFR}_{\mathrm{t}-\mathrm{i}} \\
\text { (p-value F-stat) }\end{array}$ & $\begin{array}{c}-0.00367^{* * *} \\
(0.005)\end{array}$ & $\begin{array}{l}0.00384 \\
(0.108)\end{array}$ & $\begin{array}{c}0.00480 \\
(0.262)\end{array}$ & $\begin{array}{c}-0.00735 \\
(0.344)\end{array}$ & $\begin{array}{c}0.04821 \\
(0.295)\end{array}$ \\
\hline No. Banks & 9677 & 3155 & 1231 & 750 & 148 \\
\hline $\mathrm{N}$ & 408,261 & 76,354 & 23,432 & 17,507 & 4312 \\
\hline R-sq. Within/betw./overall & $0.318 / 0.960 / 0.982$ & $0.278 / 0.855 / 0.719$ & $0.006 / 0.792 / 0.480$ & $0.002 / 0.864 / 0.308$ & $0.187 / 0.905 / 0.557$ \\
\hline
\end{tabular}


growth for small banks equal to $0.37 \%$. While small banks account for roughly only $6 \%$ of total net loans in the last period of this sample, this response corresponds to a reduction in lending supply of over $\$ 1.6 \mathrm{~B}$, mostly to households and small businesses that most rely on banks as a source of funds.

For robustness, Table 5 and Table 6 show the results for a regression models specified as above, except utilizing a fixed effects transformation rather than first difference. The goal of the transformation is the same, in that both will remove the inconsistency caused by unobserved heterogeneity correlated with observed covariates. Again, results are consistent with either the Broad exchange rate index (Table 5) and the Major Currency index (Table 6) having significant long run impacts on total net lending.

Interestingly, we see in the Fixed Effects model for the broad index in Table 5 that there is a significant role for cross-border lending in enhancing exchange rate sensitivity for all bank size categories. The sum of four quarterly lag coefficients in the interaction between the index and cross border lending is significant at the $1 \%$ level even for the largest bank categories.

\subsection{Regression Model 2: Cross-Border Loan Sensitivity to Exchange Rates-All Banks}

In order to isolate the channels through which exchange rates are hypothesized to influence lending, an equation is estimated in which the dependent variable is Cross-Border Loans, rather than total net lending. Again, a dynamic panel IV framework is utilized, with the second lag of the dependent variable acting as the instrument for the first lag. The same controls are used as found in Equation (1) above, with the addition of lagged total net loans, and the removal of the interactions between exchange rate and foreign loans.

According to the hypothesized transfer risk and currency mismatch channels, there should be an unambiguously negative partial effect of exchange rates (dollar valuation) on foreign loans, now that the potential

Table 5. Exchange rate sensitivity of total net lending (Broad index)-fixed effects. Panel dynamic fixed effects specification. Estimation sample 1990Q1-2007Q1. Autoregressive term is instrumented with second lag in differenced total net lending. Additional Controls include four lags of unemployment, CPI, housing price index, single lag of bank level equity-asset ratio, single lag of total deposits, three quarterly dummy variables.

\begin{tabular}{|c|c|c|c|c|c|}
\hline & \multicolumn{5}{|c|}{ Bank Size } \\
\hline & Smallest 75th & 75th - 90th & 90th - 95th & 95th - 99th & Top 1\% \\
\hline \multicolumn{6}{|l|}{$\triangle$ EX.RATE } \\
\hline Lag 1 & $\begin{array}{c}-0.00016 * \\
(0.073)\end{array}$ & $\begin{array}{c}-0.00055^{*} \\
(0.061)\end{array}$ & $\begin{array}{c}-0.00078 \\
(0.146)\end{array}$ & $\begin{array}{c}0.00035 \\
(0.661)\end{array}$ & $\begin{array}{c}0.00162 \\
(0.309)\end{array}$ \\
\hline Lag 2 & $\begin{array}{c}-0.00049^{* * *} \\
(0.000)\end{array}$ & $\begin{array}{c}-0.00117^{* * *} \\
(0.002)\end{array}$ & $\begin{array}{c}-0.00092 \\
(0.182)\end{array}$ & $\begin{array}{c}-0.00086 \\
(0.406)\end{array}$ & $\begin{array}{c}-0.00313 \\
(0.127)\end{array}$ \\
\hline Lag 3 & $\begin{array}{c}-0.00005 \\
(0.606)\end{array}$ & $\begin{array}{c}0.00093^{* * *} \\
(0.007)\end{array}$ & $\begin{array}{c}0.00107^{*} \\
(0.090)\end{array}$ & $\begin{array}{c}-0.00014 \\
(0.880)\end{array}$ & $\begin{array}{c}0.00248 \\
(0.190)\end{array}$ \\
\hline Lag 4 & $\begin{array}{c}0.00043^{* * *} \\
(0.000)\end{array}$ & $\begin{array}{c}0.00037 \\
(0.144)\end{array}$ & $\begin{array}{c}0.00029 \\
(0.537)\end{array}$ & $\begin{array}{c}-0.00026 \\
(0.713)\end{array}$ & $\begin{array}{c}-0.00033 \\
(0.812)\end{array}$ \\
\hline $\begin{array}{c}\Sigma \Delta \text { EX.RATE }_{\mathrm{t}} \\
\text { (p-value F-stat) }\end{array}$ & $\begin{array}{c}-0.00027 \\
(\mathbf{0 . 0 0 0 )}\end{array}$ & $\begin{array}{c}-0.00042^{* * *} \\
(0.009)\end{array}$ & $\begin{array}{c}-0.00034 \\
(0.245)\end{array}$ & $\begin{array}{c}-0.00091^{* *} \\
(0.033)\end{array}$ & $\begin{array}{c}0.00063 \\
(0.466)\end{array}$ \\
\hline $\begin{array}{c}\Sigma \Delta \text { EX.RATE }{ }_{\mathrm{t}-\mathrm{i}}^{*} \\
\text { (cross-bdr loans) } \\
\text { (p-value F-stat) }\end{array}$ & $\begin{array}{c}-3.15 e^{-08} 8^{* * *} \\
(0.000)\end{array}$ & $\begin{array}{c}-9.77 \mathbf{e}^{-09^{* * *}} \\
(0.000)\end{array}$ & $\begin{array}{c}-7.77 e^{-09} 9^{* * *} \\
(0.000)\end{array}$ & $\begin{array}{c}-1.56 e^{-10}{ }^{*} \\
(0.078)\end{array}$ & $\begin{array}{c}-1.81 e^{-11} 1^{* * *} \\
(0.002)\end{array}$ \\
\hline $\begin{array}{c}\Sigma \Delta \mathrm{FFR}_{\mathrm{t}-\mathrm{i}} \\
\text { (p-value F-stat) }\end{array}$ & $\begin{array}{c}-0.00429^{* * *} \\
(0.000)\end{array}$ & $\begin{array}{c}-0.00756^{* * *} \\
(0.000)\end{array}$ & $\begin{array}{c}-0.00524^{* *} \\
(0.043)\end{array}$ & $\begin{array}{c}-0.00927^{* *} \\
(0.015)\end{array}$ & $\begin{array}{c}0.00425 \\
(581)\end{array}$ \\
\hline No. Banks & 9744 & 3262 & 1280 & 781 & 153 \\
\hline $\mathrm{N}$ & 419,375 & 81,279 & 25,393 & 18,556 & 4524 \\
\hline R-sq. Within/betw./overall & 0.966/0.989/0.990 & 0.886/0.954/0.944 & 0.848/0.935/0.931 & 0.866/0.969/0.945 & 0.936/0.984/0.971 \\
\hline
\end{tabular}


Table 6. Exchange rate sensitivity of total net lending (Major currency index) Fixed effects. Panel dynamic fixed effects specification. Estimation sample 1990Q1-2007Q1. Autoregressive term is instrumented with second lag in differenced total net lending. Additional controls include four lags of unemployment, CPI, housing price index, single lag of bank level equity-asset ratio, single lag of total deposits, three quarterly dummy variables.

\begin{tabular}{|c|c|c|c|c|c|}
\hline & \multicolumn{5}{|c|}{ Bank Size } \\
\hline & Smallest 75th & 75th - 90th & 90th - 95th & 95th - 99th & Тор 1\% \\
\hline \multicolumn{6}{|l|}{$\triangle$ EX.RATE } \\
\hline Lag 1 & $\begin{array}{c}0.00014^{*} \\
(0.056)\end{array}$ & $\begin{array}{c}0.00005 \\
(0.834)\end{array}$ & $\begin{array}{c}-0.00009 \\
(0.841)\end{array}$ & $\begin{array}{l}0.00068 \\
(0.306)\end{array}$ & $\begin{array}{c}0.00228 * \\
(0.080)\end{array}$ \\
\hline Lag 2 & $\begin{array}{c}-0.00029^{* * *} \\
(0.001)\end{array}$ & $\begin{array}{c}-0.00102 \\
(0.001)\end{array}$ & $\begin{array}{c}-0.00084 \\
(0.141)\end{array}$ & $\begin{array}{c}-0.00031 \\
(0.391)\end{array}$ & $\begin{array}{c}-0.00296{ }^{*} \\
(0.078)\end{array}$ \\
\hline Lag 3 & $\begin{array}{c}0.00004 \\
(0.607)\end{array}$ & $\begin{array}{c}0.00065^{* *} \\
(0.018)\end{array}$ & $\begin{array}{c}0.00056 \\
(0.267)\end{array}$ & $\begin{array}{c}-0.00065 \\
(0.386)\end{array}$ & $\begin{array}{c}0.00053 \\
(0.725)\end{array}$ \\
\hline Lag 4 & $\begin{array}{c}-0.00022^{* * *} \\
(0.001)\end{array}$ & $\begin{array}{c}-0.00030 \\
(0.169)\end{array}$ & $\begin{array}{c}-0.00020 \\
(0.632)\end{array}$ & $\begin{array}{c}-0.00071 \\
(0.237)\end{array}$ & $\begin{array}{c}-0.00034 \\
(0.778)\end{array}$ \\
\hline $\begin{array}{c}\Sigma \Delta \mathrm{EX}_{\mathrm{BATE}} \\
\text { (p-value F-stat) }\end{array}$ & $\begin{array}{c}-0.00033^{* * *} \\
(0.000)\end{array}$ & $\begin{array}{c}-0.00062^{* * *} \\
(0.000)\end{array}$ & $\begin{array}{c}-0.00056^{* *} \\
(0.028)\end{array}$ & $\begin{array}{c}-0.00142^{* * *} \\
(0.000)\end{array}$ & $\begin{array}{c}-0.00049 \\
(0.516)\end{array}$ \\
\hline $\begin{array}{c}\Sigma \Delta \mathrm{EX} . \mathrm{RATE}_{\mathrm{t}-\mathrm{i}}{ }^{*} \\
\text { (cross-bdr loans) } \\
\text { (p-value F-stat) }\end{array}$ & $\begin{array}{c}-3.90 \mathrm{e}-08^{* * *} \\
(0.000)\end{array}$ & $\begin{array}{c}-1.26 e^{-08} 8^{* * *} \\
(0.000)\end{array}$ & $\begin{array}{c}-8.92 e^{-09} 9^{* * *} \\
(0.000)\end{array}$ & $\begin{array}{l}-1.68 \mathrm{e}-10 \\
(0.151)\end{array}$ & $\begin{array}{c}-2.03 e^{-11}{ }^{* *} \\
(0.011)\end{array}$ \\
\hline $\begin{array}{c}\Sigma \Delta \mathrm{FFR}_{\mathrm{t}-\mathrm{i}} \\
\text { (p-value F-stat) }\end{array}$ & $\begin{array}{c}-0.00429 * * * \\
(0.000)\end{array}$ & $\begin{array}{c}-0.00786 \text { *** } \\
(0.000)\end{array}$ & $\begin{array}{c}-0.00567^{* * *} \\
(\mathbf{0 . 0 0 0 )}\end{array}$ & $\begin{array}{c}-0.01085^{* * *} \\
(\mathbf{0 . 0 0 0 )}\end{array}$ & $\begin{array}{c}-0.00382 \\
(0.526)\end{array}$ \\
\hline No. Banks & 9744 & 3262 & 1280 & 781 & 153 \\
\hline $\mathrm{N}$ & 419,375 & 81,279 & 25,393 & 18,556 & 4524 \\
\hline R-sq. Within/betw./overall & $0.965 / 0.953 / 0.980$ & 0.885/0.953/0.944 & $0.847 / 0.935 / 0.930$ & 0.865/0.969/0.945 & $0.936 / 0.984 / 0.972$ \\
\hline
\end{tabular}

confounding effects of domestic loan demand is removed. Table 7 shows the key model results below.

As anticipated, we see evidence of the combined effects of currency mismatch and transfer risk, with every significant coefficient being negative. The strongest reactions are in the smaller bank categories, with strongly negative long-term impacts, based on the summation of the four lagged coefficients. The magnitude of the long run multiplier for log difference in the exchange rate is the cumulative effect of a $1 \%$ change in growth rate of the exchange rate on the growth in levels of Cross-Border lending. For the small bank category, the multiplier of -0.0855 translates to a reduction in growth of Cross-Border lending of $1.4 \%$ for each $1 \%$ change in the exchange rate index.

Table 8 shows that, among smaller bank categories, sensitivity of foreign lending increases as the magnitude of quarterly changes in the exchange rate index grows. This regression includes four quarterly lags of the interaction between an indicator of quarterly difference in exchange rate index greater than one sample standard deviation and the index itself.

Table 9 shows the response of cross-border loans to dollar exchange rates of specific currencies. For UK and Canada, we see significant negative long-run multipliers, consistent with the conjecture of transfer risk and currency mismatch balance sheet effects. The effect is significant only for smaller banks for the Euro, and is not significant at all for responses to changes in the value of the Chinese Renminbi relative to the dollar. The lack of significant sensitivity to the Dollar/Renminbi rate may be due to the fixed exchange rate regime employed by Chinese monetary authorities, which reduces the cost of hedging among local borrowers, and greatly mitigates transfer risk (see [13]).

\subsection{Regression Model 3: Exchange Rate Sensitivity of Non-Performing Loans}

If the significant response of total net lending to exchange rates found in Table 3 and Table 4 can be attributed 
Table 7. Exchange rate sensitivity of cross-border lending (Broad index). Panel dynamic first difference specification. Estimation sample 1990Q1-2007Q1. Autoregressive term is instrumented with second lag in differenced total net lending. Additional controls include four lags of unemployment, CPI, housing price index, single lag of bank level equity-asset ratio, single lag of total deposits, three quarterly dummy variables.

\begin{tabular}{|c|c|c|c|c|c|}
\hline & \multicolumn{5}{|c|}{ Bank Size } \\
\hline & $<75$ th & 75th - 90th & 90th - 95th & 95th - 99th & Top 1\% \\
\hline \multicolumn{6}{|l|}{$\Delta \log (\mathrm{EX} . \mathrm{RATE})$} \\
\hline Lag 1 & $\begin{array}{c}-0.0592^{* * *} \\
(0.001)\end{array}$ & $\begin{array}{c}-0.3931^{* * *} \\
(0.009)\end{array}$ & $\begin{array}{c}-0.4923 \\
(0.228)\end{array}$ & $\begin{array}{c}-0.2113 \\
(0.744)\end{array}$ & $\begin{array}{c}-0.7629 \\
(0.566)\end{array}$ \\
\hline Lag 2 & $\begin{array}{l}0.0082 \\
(0.641)\end{array}$ & $\begin{array}{l}0.2024 \\
(0.162)\end{array}$ & $\begin{array}{l}0.3621 \\
(0.361)\end{array}$ & $\begin{array}{c}-0.6594 \\
(0.291)\end{array}$ & $\begin{array}{c}-3.1252^{* *} \\
(\mathbf{0 . 0 1 5 )}\end{array}$ \\
\hline Lag 3 & $\begin{array}{c}-0.0568^{* * *} \\
(0.001)\end{array}$ & $\begin{array}{c}-0.3529 * * \\
(0.013)\end{array}$ & $\begin{array}{l}0.07437 \\
(0.848)\end{array}$ & $\begin{array}{c}-0.1396 \\
(0.819)\end{array}$ & $\begin{array}{l}1.4723 \\
(0.244)\end{array}$ \\
\hline Lag 4 & $\begin{array}{l}0.0222 \\
(0.183)\end{array}$ & $\begin{array}{l}-0.1456 \\
(0.286)\end{array}$ & $\begin{array}{c}-0.7635^{* *} \\
(0.042)\end{array}$ & $\begin{array}{c}-0.3740 \\
(0.527)\end{array}$ & $\begin{array}{c}-0.4119 \\
(0.737)\end{array}$ \\
\hline $\begin{array}{c}\Sigma \Delta \log (\text { EX.RATE) } \\
\text { (p-value F-stat) }\end{array}$ & $\begin{array}{c}-0.0855^{* * *} \\
(0.005)\end{array}$ & $\begin{array}{l}-0.6892^{* * *} \\
(\mathbf{0 . 0 0 5 )}\end{array}$ & $\begin{array}{c}-0.8194 \\
(0.224)\end{array}$ & $\begin{array}{c}-1.3843 \\
(0.190)\end{array}$ & $\begin{array}{c}-2.8277 \\
(0.203)\end{array}$ \\
\hline \multicolumn{6}{|l|}{$\Delta \mathrm{FFR}$} \\
\hline Lag 1 & $\begin{array}{c}-0.0040 \\
(0.004)\end{array}$ & $\begin{array}{l}0.0014 \\
(0.902)\end{array}$ & $\begin{array}{c}-0.0360 \\
(0.245)\end{array}$ & $\begin{array}{l}0.0520 \\
(0.286)\end{array}$ & $\begin{array}{l}0.0897 \\
(0.373)\end{array}$ \\
\hline Lag 2 & $\begin{array}{l}0.0011 \\
(0.482)\end{array}$ & $\begin{array}{l}0.0015 \\
(0.910)\end{array}$ & $\begin{array}{l}0.0650^{*} \\
(0.066)\end{array}$ & $\begin{array}{c}-0.0317 \\
(0.571)\end{array}$ & $\begin{array}{c}-0.0341 \\
(0.767)\end{array}$ \\
\hline Lag 3 & $\begin{array}{c}-0.0018 \\
(0.256)\end{array}$ & $\begin{array}{c}-0.0175 \\
(0.185)\end{array}$ & $\begin{array}{c}-0.0769^{* *} \\
(0.034)\end{array}$ & $\begin{array}{c}-0.0844 \\
(0.140)\end{array}$ & $\begin{array}{c}-0.1757 \\
(0.134)\end{array}$ \\
\hline Lag 4 & $\begin{array}{c}-0.0012 \\
(0.390)\end{array}$ & $\begin{array}{c}-0.0055 \\
(0.636)\end{array}$ & $\begin{array}{l}0.03847 \\
(0.227)\end{array}$ & $\begin{array}{l}0.0780 \\
(0.122)\end{array}$ & $\begin{array}{l}0.0724 \\
(0.483)\end{array}$ \\
\hline $\mathrm{R}^{2}$ : Within/betw/overall & $0.262 / 0.012 / 0.661$ & $0.050 / 0.001 / 0.647$ & $0.237 / 0.062 / 0.889$ & $0.280 / 0.013 / 0.388$ & $0.017 / 0.004 / 0.118$ \\
\hline No. Banks & 9677 & 3155 & 1232 & 750 & 148 \\
\hline $\mathrm{N}$ & 408,263 & 76,356 & 23,438 & 17,511 & 4313 \\
\hline
\end{tabular}

to a "weakening" of the balance sheet, then it should be the case that there exists a meaningful positive relationship between currency value and non-performing loans on the balance sheet. This suggests estimating the dynamic panel first-difference model with a delinquent loans measure as the dependent variable. Table 10 shows these results with loans at least 90 days delinquent as the measure of interest, and the broad exchange rate index as the currency value measure.

Consistent with prior results, it is the smallest bank size that displays the greatest sensitivity. The key results above are these: 1) a dollar appreciation, holding interest rates constant, is associated with a significant long run increase in non-performing loans on balance sheets of small banks, and 2) as seen from the significant interaction terms, small banks that hold cross-border loans are more susceptible to this effect. This is exactly the scenario predicted by the transfer risk and credit mismatch hypothesis regarding the role of exchange rates in bank lending.

The magnitudes of exchange rate response of non-performing loans for small banks can be seen in the change in the difference in response to a one standard deviation increase in the broad index. The average change in non-performing loans in the sample for small banks is positive $0.7 \%$, the change following a one standard deviation increase in the broad index is estimated to be over $2.7 \%$, a four-fold increase in delinquent loan growth.

It is also worth noting from Table 10 that monetary tightening, as represented by an increase in the Federal Funds rate, is associated with a long run weakening of the balance sheet for all but the largest $5 \%$ of banks. 
Table 8. Exchange rate sensitivity of cross-border lending (Broad index) additional impact of large changes in exchange rates. Panel dynamic first difference specification. Estimation sample 1990Q1-2007Q1. Autoregressive term is instrumented with second lag in differenced total net lending. Additional controls include four lags of unemployment, CPI, housing price index, single lag of bank level equity-asset ratio, single lag of total deposits, three quarterly dummy variables.

\begin{tabular}{|c|c|c|c|c|c|}
\hline & \multicolumn{5}{|c|}{ Bank Size } \\
\hline & Smallest 75th & 75th - 90th & 90th - 95th & 95th - 99th & Top $1 \%$ \\
\hline \multicolumn{6}{|l|}{$1 \mathrm{SD}(=1)^{*} \Delta \log (\mathrm{EX} . \mathrm{RATE})$} \\
\hline Lag 1 & $\begin{array}{c}-0.0003^{*} \\
(0.053)\end{array}$ & $\begin{array}{c}-0.0023^{*} \\
(0.068)\end{array}$ & $\begin{array}{l}0.0036 \\
(0.292)\end{array}$ & $\begin{array}{l}0.0036 \\
(0.507)\end{array}$ & $\begin{array}{l}0.0058 \\
(0.608)\end{array}$ \\
\hline Lag 2 & $\begin{array}{c}-0.0004^{*} \\
(0.032)\end{array}$ & $\begin{array}{c}-0.0044^{* * *} \\
(0.006)\end{array}$ & $\begin{array}{c}-0.0076 * \\
(0.079)\end{array}$ & $\begin{array}{c}-0.0023 \\
(0.736)\end{array}$ & $\begin{array}{c}-0.0189 \\
(0.178)\end{array}$ \\
\hline Lag 3 & $\begin{array}{c}-0.0009^{* * *} \\
(0.000)\end{array}$ & $\begin{array}{c}-0.0007 \\
(0.675)\end{array}$ & $\begin{array}{l}0.0052 \\
(0.254)\end{array}$ & $\begin{array}{l}0.0040 \\
(0.578)\end{array}$ & $\begin{array}{c}-0.0242 \\
(0.101)\end{array}$ \\
\hline Lag 4 & $\begin{array}{c}-0.0002 \\
(0.241)\end{array}$ & $\begin{array}{c}-0.0021 \\
(0.115)\end{array}$ & $\begin{array}{c}-0.0042 \\
(0.240)\end{array}$ & $\begin{array}{l}0.0011 \\
(0.851)\end{array}$ & $\begin{array}{c}-0.0138 \\
(0.236)\end{array}$ \\
\hline \multicolumn{6}{|l|}{$\Delta \log ($ EX.RATE) } \\
\hline Lag 1 & $\begin{array}{c}-0.0224 \\
(0.293)\end{array}$ & $\begin{array}{c}-0.5110^{* * *} \\
(0.003)\end{array}$ & $\begin{array}{c}-1.4269^{* * *} \\
(0.003)\end{array}$ & $\begin{array}{c}-0.6100 \\
(0.422)\end{array}$ & $\begin{array}{c}-0.5697 \\
(0.714)\end{array}$ \\
\hline Lag 2 & $\begin{array}{l}0.0023 \\
(0.906)\end{array}$ & $\begin{array}{c}0.4162^{* * *} \\
(0.010)\end{array}$ & $\begin{array}{l}1.1351^{* *} \\
(0.011)\end{array}$ & $\begin{array}{c}-0.3905 \\
(0.579)\end{array}$ & $\begin{array}{c}-2.5335^{*} \\
(0.080)\end{array}$ \\
\hline Lag 3 & $\begin{array}{c}-0.0433^{* *} \\
(0.017)\end{array}$ & $\begin{array}{c}-0.5189^{* * *} \\
(0.000)\end{array}$ & $\begin{array}{c}-0.4196 \\
(0.304)\end{array}$ & $\begin{array}{c}-0.3155 \\
(0.624)\end{array}$ & $\begin{array}{l}1.4561 \\
(0.274)\end{array}$ \\
\hline Lag 4 & $\begin{array}{c}-0.0023 \\
(0.900)\end{array}$ & $\begin{array}{c}-0.1237 \\
(0.401)\end{array}$ & $\begin{array}{c}-0.6229 \\
(0.123)\end{array}$ & $\begin{array}{c}-0.3764 \\
(0.554)\end{array}$ & $\begin{array}{c}-0.9579 \\
(0.472)\end{array}$ \\
\hline $\begin{array}{c}\Sigma \Delta \log (\text { EX.RATE })+\Sigma 1 S D(=1)^{*} \\
\Delta \log (\text { EX.RATE }) \\
\text { (p-value F-stat) }\end{array}$ & $\begin{array}{c}-0.0674^{* *} \\
(0.029)\end{array}$ & $\begin{array}{c}-0.7468^{* * *} \\
(0.003)\end{array}$ & $\begin{array}{c}-1.3373^{*} \\
(0.052)\end{array}$ & $\begin{array}{c}-1.68598 \\
(0.118)\end{array}$ & $\begin{array}{c}-2.66754 \\
(0.238)\end{array}$ \\
\hline
\end{tabular}

Table 9. Exchange rate sensitivity of cross-border lending (Individual currencies). Panel dynamic first difference specification. Estimation sample 1990Q1-2007Q1. Autoregressive term is instrumented with second lag in differenced total net lending. Additional controls include four lags of unemployment, CPI, housing price index, single lag of bank level equityasset ratio, single lag of total deposits, three quarterly dummy variables. P-values derived from heteroskedasticity robust standard errors.

(a)

\begin{tabular}{|c|c|c|c|c|c|}
\hline \multicolumn{6}{|c|}{ Canada-US Dollar (1991Q1-2007Q1) } \\
\hline & \multicolumn{5}{|c|}{ Bank Size } \\
\hline & Smallest 75th & 75th - 90th & 90th - 95th & 95th - 99th & Top 1\% \\
\hline \multicolumn{6}{|l|}{$\Delta \log (\mathrm{EX} . \mathrm{RATE})$} \\
\hline Lag 1 & $\begin{array}{c}-0.0716^{* * *} \\
(0.000)\end{array}$ & $\begin{array}{c}-0.5639^{* * *} \\
(0.000)\end{array}$ & $\begin{array}{c}-0.3603 \\
(0.353)\end{array}$ & $\begin{array}{l}0.1215 \\
(0.843)\end{array}$ & $\begin{array}{l}-1.5028 \\
(0.232)\end{array}$ \\
\hline Lag 2 & $\begin{array}{l}0.0149 \\
(0.367)\end{array}$ & $\begin{array}{l}0.2417^{*} \\
(0.076)\end{array}$ & $\begin{array}{c}-0.1308 \\
(0.725)\end{array}$ & $\begin{array}{c}-1.2985^{* *} \\
(0.026)\end{array}$ & $\begin{array}{l}-1.4499 \\
(0.229)\end{array}$ \\
\hline Lag 3 & $\begin{array}{c}-0.0612^{* * *} \\
(\mathbf{0 . 0 0 0 )}\end{array}$ & $\begin{array}{c}-0.3718 * * * \\
(0.005)\end{array}$ & $\begin{array}{l}0.2253 \\
(0.538)\end{array}$ & $\begin{array}{c}-0.0622 \\
(0.914)\end{array}$ & $\begin{array}{r}-0.3735 \\
(0.753)\end{array}$ \\
\hline Lag 4 & $\begin{array}{l}0.0391^{* *} \\
(0.018)\end{array}$ & $\begin{array}{l}0.1581 \\
(0.241)\end{array}$ & $\begin{array}{l}0.4543 \\
(0.217)\end{array}$ & $\begin{array}{c}-0.5777 \\
(0.317)\end{array}$ & $\begin{array}{l}0.0717 \\
(0.953)\end{array}$ \\
\hline $\begin{array}{c}\Sigma \Delta \log (\text { EX.RATE }) \\
\text { (p-value F-stat) }\end{array}$ & $\begin{array}{l}-0.0788 \text { *** } \\
(\mathbf{0 . 0 0 3 )}\end{array}$ & $\begin{array}{c}-0.5360^{* *} \\
(0.014)\end{array}$ & $\begin{array}{c}-0.7201 \\
(0.224)\end{array}$ & $\begin{array}{c}-1.8169 * \\
(0.051)\end{array}$ & $\begin{array}{r}-3.2544 \\
(0.092)\end{array}$ \\
\hline
\end{tabular}

Source: Federal reserve economic database. 
(b)

\begin{tabular}{|c|c|c|c|c|c|}
\hline \multicolumn{6}{|c|}{ UK-US Dollar (1991Q1-2007Q1) } \\
\hline & \multicolumn{5}{|c|}{ Bank Size } \\
\hline & Smallest 75th & 75th - 90th & 90th - 95th & 95th - 99th & Top $1 \%$ \\
\hline \multicolumn{6}{|l|}{$\Delta \log ($ EX.RATE $)$} \\
\hline Lag 1 & $\begin{array}{c}-0.02160^{* *} \\
(0.029)\end{array}$ & $\begin{array}{c}-0.2992^{* * *} \\
(0.000)\end{array}$ & $\begin{array}{c}-0.7663^{* * *} \\
(0.001)\end{array}$ & $\begin{array}{l}-0.8055^{* *} \\
(0.023)\end{array}$ & $\begin{array}{l}0.1529 \\
(0.831)\end{array}$ \\
\hline Lag 2 & $\begin{array}{l}-0.01064 \\
(0.282)\end{array}$ & $\begin{array}{l}0.0358 \\
(0.662)\end{array}$ & $\begin{array}{l}0.1715 \\
(0.449)\end{array}$ & $\begin{array}{c}-0.2030 \\
(0.569)\end{array}$ & $\begin{array}{r}-1.3657^{*} \\
(0.059)\end{array}$ \\
\hline Lag 3 & $\begin{array}{l}-0.00755 \\
(0.415)\end{array}$ & $\begin{array}{c}-0.0602 \\
(0.431)\end{array}$ & $\begin{array}{l}0.1515 \\
(0.443)\end{array}$ & $\begin{array}{c}-0.2043 \\
(0.537)\end{array}$ & $\begin{array}{l}0.1697 \\
(0.804)\end{array}$ \\
\hline Lag 4 & $\begin{array}{c}-0.01554^{*} \\
(0.075)\end{array}$ & $\begin{array}{c}-0.0501 \\
(0.486)\end{array}$ & $\begin{array}{c}-0.5010^{* *} \\
(0.012)\end{array}$ & $\begin{array}{c}-0.5924^{*} \\
(0.059)\end{array}$ & $\begin{array}{l}-1.061^{*} \\
(0.099)\end{array}$ \\
\hline $\begin{array}{c}\Sigma \Delta \log (\text { EX.RATE }) \\
\text { (p-value F-stat) }\end{array}$ & $\begin{array}{l}-0.0553^{* * *} \\
(0.002)\end{array}$ & $\begin{array}{c}-0.0501^{* *} \\
(0.011)\end{array}$ & $\begin{array}{c}-0.9444^{* *} \\
(0.019)\end{array}$ & $\begin{array}{l}-1.8052^{* * *} \\
(0.004)\end{array}$ & $\begin{array}{l}-2.1038 \\
(0.107)\end{array}$ \\
\hline
\end{tabular}

(c)

\begin{tabular}{|c|c|c|c|c|c|}
\hline \multicolumn{6}{|c|}{ Dollar-Renminbi (CNY) (1991Q1-2007Q1) } \\
\hline & \multicolumn{5}{|c|}{ Bank Size } \\
\hline & Smallest 75th & 75th - 90th & 90th - 95th & 95th - 99th & Top $1 \%$ \\
\hline \multicolumn{6}{|l|}{$\Delta \log (\mathrm{EX} . \mathrm{RATE})$} \\
\hline Lag 1 & $\begin{array}{c}0.00012 \\
(0.985)\end{array}$ & $\begin{array}{c}-0.0820 \\
(0.108)\end{array}$ & $\begin{array}{c}0.03474 \\
(0.806)\end{array}$ & $\begin{array}{c}-0.1664 \\
(0.449)\end{array}$ & $\begin{array}{r}-0.1679 \\
(0.713)\end{array}$ \\
\hline Lag 2 & $\begin{array}{l}-0.00260 \\
(0.676)\end{array}$ & $\begin{array}{l}-0.01629 \\
(0.753)\end{array}$ & $\begin{array}{c}-0.03206 \\
(0.821)\end{array}$ & $\begin{array}{c}-0.1971 \\
(0.377)\end{array}$ & $\begin{array}{l}0.1217 \\
(0.791)\end{array}$ \\
\hline Lag 3 & $\begin{array}{c}-0.00847 \\
(0.167)\end{array}$ & $\begin{array}{l}\mathbf{0 . 1 0 3 6}^{* *} \\
(0.042)\end{array}$ & $\begin{array}{c}-0.04124 \\
(0.768)\end{array}$ & $\begin{array}{l}0.3066 \\
(0.169)\end{array}$ & $\begin{array}{l}0.1844 \\
(0.683)\end{array}$ \\
\hline $\operatorname{Lag} 4$ & $\begin{array}{c}0.00439 \\
(0.492)\end{array}$ & $\begin{array}{c}-0.1158^{* *} \\
(0.029)\end{array}$ & $\begin{array}{c}-0.10483 \\
(0.471)\end{array}$ & $\begin{array}{c}-0.2079 \\
(0.370)\end{array}$ & $\begin{array}{c}1.0518^{* *} \\
(0.024)\end{array}$ \\
\hline $\begin{array}{c}\Sigma \Delta \log (\text { EX.RATE }) \\
\text { (p-value F-stat) }\end{array}$ & $\begin{array}{c}-0.0066 \\
(0.596)\end{array}$ & $\begin{array}{c}-0.1105 \\
(0.283)\end{array}$ & $\begin{array}{c}-0.1434 \\
(0.613)\end{array}$ & $\begin{array}{c}-0.2649 \\
(0.554)\end{array}$ & $\begin{array}{l}1.1900 \\
(0.193)\end{array}$ \\
\hline
\end{tabular}

(d)

\begin{tabular}{|c|c|c|c|c|c|}
\hline \multicolumn{6}{|c|}{ Euro-US Dollar (1999Q1-2007Q1) } \\
\hline & \multicolumn{5}{|c|}{ Bank Size } \\
\hline & Smallest 75th & 75th - 90th & 90th - 95th & 95th - 99th & Top $1 \%$ \\
\hline \multicolumn{6}{|l|}{$\Delta \log (\mathrm{EX} . \mathrm{RATE})$} \\
\hline Lag 1 & $\begin{array}{l}0.1132^{* * *} \\
(0.000)\end{array}$ & $\begin{array}{l}0.6430 \\
(0.001)\end{array}$ & $\begin{array}{c}-0.2671 \\
(0.540)\end{array}$ & $\begin{array}{l}0.6538 \\
(0.456)\end{array}$ & $\begin{array}{r}-2.2637 \\
(0363)\end{array}$ \\
\hline Lag 2 & $\begin{array}{c}-0.0340^{*} \\
(0.070)\end{array}$ & $\begin{array}{c}-0.1163 \\
(0.506)\end{array}$ & $\begin{array}{l}0.2693 \\
(0.478)\end{array}$ & $\begin{array}{c}-1.4877^{*} \\
(0.052)\end{array}$ & $\begin{array}{l}-0.9472 \\
(0.663)\end{array}$ \\
\hline Lag 3 & $\begin{array}{l}-0.0653^{* * *} \\
(0.000)\end{array}$ & $\begin{array}{c}-0.44377 \\
(0.005)\end{array}$ & $\begin{array}{c}-0.1435 \\
(0.677)\end{array}$ & $\begin{array}{c}-1.1760^{*} \\
(0.085)\end{array}$ & $\begin{array}{r}-0.5227 \\
(0.790)\end{array}$ \\
\hline Lag 4 & $\begin{array}{c}-0.0996^{* * *} \\
(0.000)\end{array}$ & $\begin{array}{c}-0.58251 \\
(0.001)\end{array}$ & $\begin{array}{l}0.3253 \\
(0.379)\end{array}$ & $\begin{array}{c}1.5933^{* *} \\
(0.032)\end{array}$ & $\begin{array}{c}-1.2566 \\
(0.548)\end{array}$ \\
\hline $\begin{array}{c}\Sigma \Delta \log (\text { EX.RATE) } \\
\text { (p-value F-stat) }\end{array}$ & $\begin{array}{l}-0.0856^{* * *} \\
(0.003)\end{array}$ & $\begin{array}{c}-0.49966^{*} \\
(0.062)\end{array}$ & $\begin{array}{l}0.1839 \\
(0.752)\end{array}$ & $\begin{array}{c}-0.4165 \\
(0.721)\end{array}$ & $\begin{array}{l}-4.9902 \\
(0.135)\end{array}$ \\
\hline
\end{tabular}


Table 10. Exchange rate sensitivity of delinquent loans (broad index). Panel dynamic first difference specification. Estimation sample 1990Q1-2007Q1. Autoregressive term is instrumented with second lag in differenced total delinquent lending. Additional controls include four lags of unemployment, CPI, housing price index, single lag of bank level equity-asset ratio, single lag of total deposits, three quarterly dummy variables. P-values derived from heteroskedasticity robust standard errors.

\begin{tabular}{|c|c|c|c|c|c|}
\hline & \multicolumn{5}{|c|}{ Bank Size } \\
\hline & Smallest 75th & 75th - 90th & 90th - 95th & 95th - 99th & Top 1\% \\
\hline \multicolumn{6}{|l|}{$\triangle$ EX.RATE } \\
\hline Lag 1 & $\begin{array}{c}0.12427 \\
(0.616)\end{array}$ & $\begin{array}{l}2.4980^{*} \\
(0.085)\end{array}$ & $\begin{array}{l}10.995 \\
(0.186)\end{array}$ & $\begin{array}{c}14.77516 \\
(0.697)\end{array}$ & $\begin{array}{l}7120.03 \\
(0.840)\end{array}$ \\
\hline Lag 2 & $\begin{array}{l}0.92338^{* * *} \\
(0.000)\end{array}$ & $\begin{array}{c}-1.0169 \\
(0.469)\end{array}$ & $\begin{array}{l}7.7263 \\
(0.338)\end{array}$ & $\begin{array}{c}-8.801441 \\
(0.811)\end{array}$ & $\begin{array}{c}34183.19 \\
(0.690)\end{array}$ \\
\hline Lag 3 & $\begin{array}{c}0.2571 \\
(0.0269)\end{array}$ & $\begin{array}{c}-0.5067 \\
(0.748)\end{array}$ & $\begin{array}{c}-12.397 \\
(0.110)\end{array}$ & $\begin{array}{l}-42.48107 \\
(0.228)\end{array}$ & $\begin{array}{l}-57295.54 \\
(0.657)\end{array}$ \\
\hline Lag 4 & $\begin{array}{c}0.6127^{* * *} \\
(0.007)\end{array}$ & $\begin{array}{l}2.3839^{*} \\
(0.074)\end{array}$ & $\begin{array}{c}4.16371 \\
(0.557)\end{array}$ & $\begin{array}{c}\text { 68.300** }^{* *} \\
(0.050)\end{array}$ & $\begin{array}{l}-55491.7 \\
(0.673)\end{array}$ \\
\hline $\begin{array}{c}\Sigma \Delta \text { EX.RATE } \\
\text { (p-value F-stat) }\end{array}$ & $\begin{array}{l}1.9174 \\
(0.000)\end{array}$ & $\begin{array}{l}3.3582 \\
(0.127)\end{array}$ & $\begin{array}{l}10.488 \\
(0.403)\end{array}$ & $\begin{array}{c}31.79286 \\
(0.557)\end{array}$ & $\begin{array}{l}-71484.02 \\
(0.665)\end{array}$ \\
\hline \multicolumn{6}{|l|}{$\begin{array}{c}\Delta \text { EX.RATE } \\
\text { (Cross-border Loans) }\end{array}$} \\
\hline Lag 1 & $\begin{array}{l}0.00020^{* * *} \\
(0.000)\end{array}$ & $\begin{array}{l}-3.96 \mathrm{e}^{-06} \\
(0.697)\end{array}$ & $\begin{array}{l}0.00003 \\
(0.393)\end{array}$ & $\begin{array}{l}-0.00002^{* * *} \\
(0.002)\end{array}$ & $\begin{array}{l}0.00083 \\
(0.669)\end{array}$ \\
\hline Lag 2 & $\begin{array}{c}0^{.00007} \\
(0.035)\end{array}$ & $\begin{array}{l}-1.98 e^{-06} \\
(0.839)\end{array}$ & $\begin{array}{c}0.00005 \\
(0.185)\end{array}$ & $\begin{array}{l}3.56 \mathrm{e}-06 \\
(0.562)\end{array}$ & $\begin{array}{l}-0.00102 \\
(0.662)\end{array}$ \\
\hline Lag 3 & $\begin{array}{c}-0.00005 \\
(\mathbf{0 . 0 0 0 )}\end{array}$ & $\begin{array}{l}-5.89 e^{-09} \\
(0.999)\end{array}$ & $\begin{array}{c}-0.00009^{* * *} \\
(\mathbf{0 . 0 0 0 )}\end{array}$ & $\begin{array}{l}-2.27 e^{-06} \\
(0.582)\end{array}$ & $\begin{array}{l}-0.00068 \\
(0.667)\end{array}$ \\
\hline Lag 4 & $\begin{array}{l}0.00005^{* * *} \\
(0.000)\end{array}$ & $\begin{array}{l}2.09 \mathrm{e}-06 \\
(0.728)\end{array}$ & $\begin{array}{l}\mathbf{0 . 0 0 0 0 6}^{* * *} \\
(0.002)\end{array}$ & $\begin{array}{c}-7.13 e^{-06}{ }^{*} \\
(0.085)\end{array}$ & $\begin{array}{l}-0.00027 \\
(0.691)\end{array}$ \\
\hline $\begin{array}{c}\Sigma \Delta \mathrm{EX} \mathrm{RATE}_{\mathrm{t}-\mathrm{i}}{ }^{*} \\
\text { (cross-bdr loans) } \\
\text { (p-value F-stat) }\end{array}$ & $\begin{array}{c}0.00027^{* * *} \\
(\mathbf{0 . 0 0 0 )}\end{array}$ & $\begin{array}{l}-3.86 \mathrm{e}^{-06} \\
(0.823)\end{array}$ & $\begin{array}{l}0.00004 \\
(0.471)\end{array}$ & $\begin{array}{c}-0.000028^{* *} \\
(0.016)\end{array}$ & $\begin{array}{l}-0.00114 \\
(0.668)\end{array}$ \\
\hline $\begin{array}{c}\Sigma \Delta \mathrm{FFR}_{\mathrm{t}-\mathrm{i}} \\
\text { (p-value F-stat) }\end{array}$ & $\begin{array}{l}12.464^{* * *} \\
(0.000)\end{array}$ & $\begin{array}{c}35.3012^{* *} \\
(0.021)\end{array}$ & $\begin{array}{l}165.46^{*} \\
(0.060)\end{array}$ & $\begin{array}{c}441.594 \\
(0.269)\end{array}$ & $\begin{array}{c}697573.2 \\
(0.664)\end{array}$ \\
\hline Number of obs. & 408,169 & 76,183 & 23,355 & 17,313 & 4269 \\
\hline Number of Banks & 9673 & 3146 & 1226 & 744 & 146 \\
\hline R-sq: within/betw/overall & $0.211 / 0.219 / 0.394$ & $0.052 / 0.116 / 0.165$ & $0.180 / 0.660 / 0.546$ & $0.463 / 0.606 / 0.788$ & $0.360 / 0.006 / 0.548$ \\
\hline
\end{tabular}

p-values in parentheses. ${ }^{*}=$ significant at $10 \%,{ }^{* *}=$ significant at $5 \%,{ }^{* * *}=$ significant at $1 \%$.

\section{Conclusions}

Evidence drawn from this investigation indicates that balance sheets and lending activity of US banks are sensitive to movements in the value of domestic currency. While this sensitivity is taken as given in small, open economies, it had not been fully investigated using bank level micro data for large industrialized economies. The sources of this sensitivity lie in the markets for both domestic and foreign loans, and for all sizes of banks, but are most acute in the smaller banks.

The results indicate that exchange rate movements have a broad effect on bank activity, influencing total domestic loans, cross-border lending, as well as the strength of balance sheets. Perhaps surprisingly, it is shown that the magnitude of small banks' long run reaction to exchange rate shocks is roughly equivalent to interest rate shocks. 


\section{References}

[1] Radelet, S., Sachs, J.D., Cooper, R.N. and Bosworth, B.P. (1998) The East Asian Financial Crisis: Diagnosis, Remedies, Prospects. Brookings Papers on Economic Activity, 1998, 1-90. http://dx.doi.org/10.2307/2534670

[2] Corsetti, G., Pesenti, P. and Roubini, N. (2001) Fundamental Determinants of the Asian Crisis: The Role of Financial Fragility and External Imbalances. In: Ito, T. and Krueger, A.O., Eds., Regional and Global Capital Flows: Macroeconomic Causes and Consequences, NBER-EASE 10, University of Chicago Press, Chicago, 11-46. http://dx.doi.org/10.7208/chicago/9780226387017.003.0002

[3] Choi, W.G. and Cook, D. (2004) Liability Dollarization and the Bank Balance Sheet Channel. Journal of International Economics, 64, 247-275. http://dx.doi.org/10.1016/j.jinteco.2003.08.009

[4] Herrmann, S. and Mihaljek, D. (2013) The Determinants of Cross-Border Bank Flows to Emerging Markets. Economics of Transition, 21, 479-508. http://dx.doi.org/10.1111/ecot.12019

[5] Cetorelli, N. and Goldberg, L. (2006) Risks in U.S. Bank International Exposures. Federal Reserve Bank of New York Staff Reports No. 240, New York.

[6] Kashyap, A. and Stein, J. (1995) The Impact of Monetary Policy on Bank Balance Sheets. Carnegie-Rochester Conference Series on Public Policy, 42, 151-195. http://dx.doi.org/10.1016/0167-2231(95)00032-U

[7] Kashyap, A. and Stein, J. (2000) What Do a Million Observations on Banks Have to Say about the Transmission of Monetary Policy? The American Economic Review, 90, 407-428. http://dx.doi.org/10.1257/aer.90.3.407

[8] Cetorelli, N. and Goldberg, L. (2012) Banking Globalization and Monetary Transmission. Journal of Finance, 67, 1811-1843. http://dx.doi.org/10.1111/j.1540-6261.2012.01773.x

[9] Aghion, P., Bacchetta, P., Ranciere, R. and Rogoff, K. (2009) Exchange Rate Volatility and Productivity Growth: The Role of Financial Development. Journal of Monetary Economics, 56, 494-513. http://dx.doi.org/10.1016/j.jmoneco.2009.03.015

[10] Erceg, C., Gust, C. and Lopez-Salido, D. (2007) The Transmission of Shocks in the Open Economy. NBER Working Paper 13613, Cambridge, Massachusetts.

[11] Woodford, M. (2007) Globalization and Monetary Control. NBER Working Paper 13329, Cambridge, Massachusetts.

[12] Smets, F. and Wouters, R. (1999) The Exchange Rate and the Monetary Transmission Mechanism in Germany. De Economist, 147, 489-521. http://dx.doi.org/10.1023/A:1003803228309

[13] Kamin, S. (2010) Financial Globalization and Monetary Policy. Board of Governors of the Federal Reserve System, International Finance Discussion Papers No. 1002.

[14] Arteta, C.O. (2005) Exchange Rate Regimes and Financial Dollarization: Does Flexibility Reduce Currency Mismatches in Banks Intermediation? Topics in Macroeconomics, 5, 738.

[15] Bernanke, B. and Blinder, A. (1992) The Federal Funds Rate and the Channels of Monetary Transmission. American Economic Review, 82, 901-922.

[16] Peek, J. and Rosengren, E. (1996) Bank Lending and the Transmission of Monetary Policy. New England Economic Review, Federal Reserve Bank of Boston, 1-29.

[17] Kishan, R. and Opiela, T. (2000) Bank Size, Bank Capital, and the Bank Lending Channel. Journal of Money, Credit and Banking, 32, 121-141. http://dx.doi.org/10.2307/2601095

[18] Anderson, T.W. and Hsiao, C. (1982) Formulation and Estimation of Dynamic Models Using Panel Data. Journal of Econometrics, 18, 47-82. http://dx.doi.org/10.1016/0304-4076(82)90095-1

[19] Arellano, M. and Bond, S. (1991) Some Tests of Specification for Panel Data: Monte Carlo Evidence and an Application to Employment Equations. Review of Economic Studies, 58, 277-297. http://dx.doi.org/10.2307/2297968

[20] Berger, A.N. and De Young, R. (2002) Technological Progress and the Geographic Expansion of the Banking Industry. Federal Reserve Bank of Chicago Working Paper WP 2002-7, Chicago.

[21] Peterson, M.A. and Rajan, R.G. (2002) Does Distance Still Matter? The Information Revolution in Small Business Lending. Journal of Finance, 57, 2533-2570. http://dx.doi.org/10.1111/1540-6261.00505 
Scientific Research Publishing (SCIRP) is one of the largest Open Access journal publishers. It is currently publishing more than 200 open access, online, peer-reviewed journals covering a wide range of academic disciplines. SCIRP serves the worldwide academic communities and contributes to the progress and application of science with its publication.

Other selected journals from SCIRP are listed as below. Submit your manuscript to us via either submit@scirp.org or Online Submission Portal.
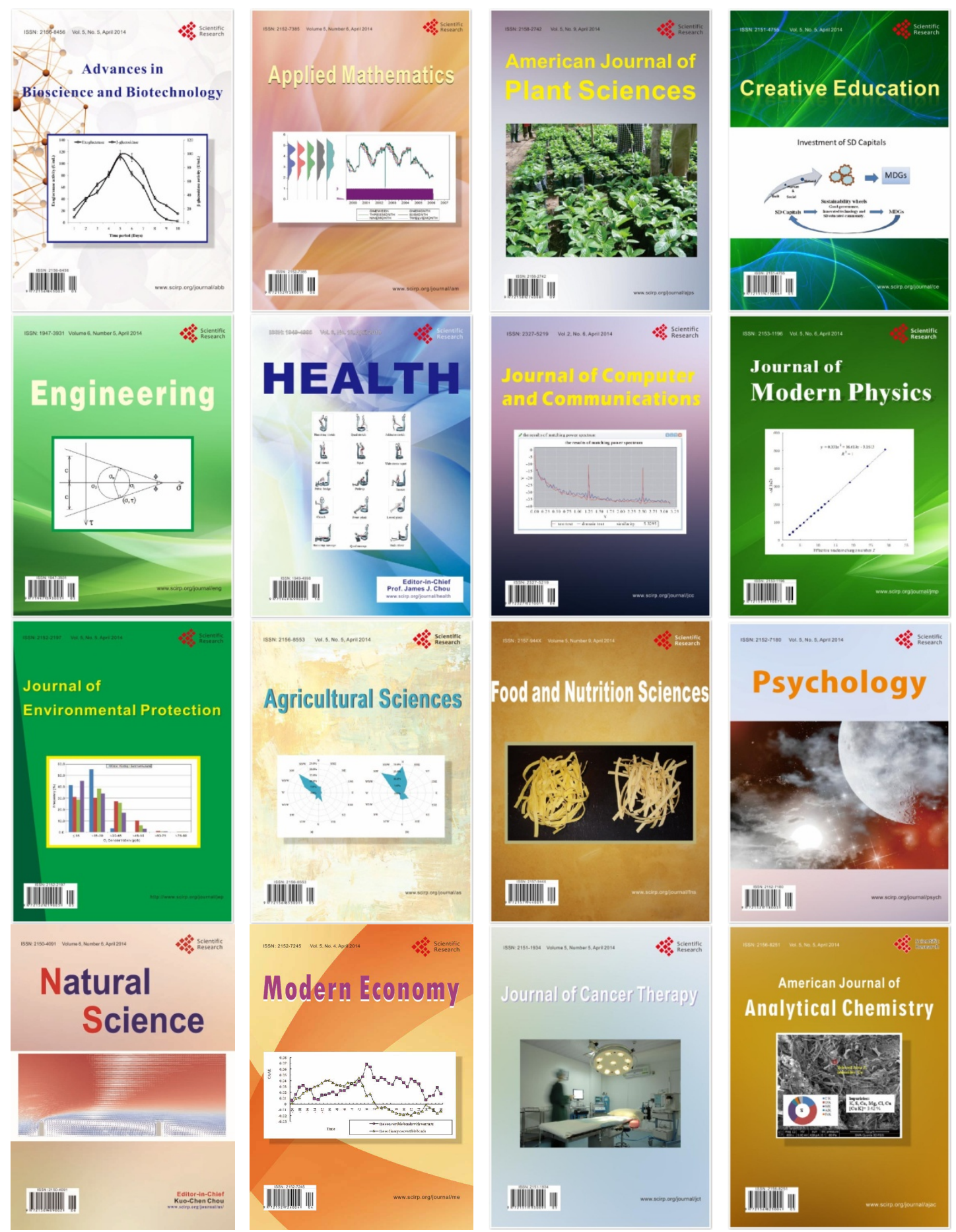